\title{
Corporate citizenship, stakeholder management and Sustainable Development Goals (SDGs) in financial institutions and capital markets
}

\author{
Jacob Dahl Rendtorff \\ Department of Social Sciences and Business, Roskilde University, Roskilde, Denmark
}

Sustainable Development Goals

\begin{abstract}
Purpose - The aim of this theoretical and conceptual research paper is to give a definition of the concept of corporate citizenship, which together with business ethics and stakeholder management function as foundation of a vision of the UN Sustainable Development Goals (SDGs) for financial institutions and capital markets.

Design/methodology/approach - This paper is based on a conceptual methodology which analyzes the main aspects of corporate citizenship with regard stakeholder management and the UNSDGs. In particular there is focus on stakeholder justice, integrity and fairness with regard to stakeholder responsibility at capital markets.

Findings - This paper suggests that concepts of corporate citizenship, business ethics, stakeholder justice, integrity and fairness, as well as stakeholder responsibility must be conceived as the basis for an acceptable vision of sustainable development at capital markets.

Research limitations/implications - This paper is a theoretical paper so the paper is limited to the presentation of major concepts from the point of view of business ethics, stakeholder management and SDGs. This is a framework that needs to be developed in specific research and investment practice at capital markets. Practical implications - This paper provides the basis for developing a good vision of SDGs in financial institutions and capital markets and it demonstrates that the SDGs must be developed as the foundation of ethics of investments and capital markets.

Social implications - With suggestions of visions of corporate citizenship, business ethics and stakeholder management this paper situates the firm in a social context as a social actor in the context of sustainable development. The business firm is therefore integrated in society and there is a close connection between business and society which needs to be developed in codes and values of ethics of financial institutions capital markets.

Originality/value - The originality and value of this paper is a conceptual formulation of the relation between the concepts of corporate citizenship, business ethics, stakeholder management and SDGs in financial markets. With this the paper refers to earlier research and summarizes concepts from this in a short synthesis.
\end{abstract}

Keywords Corporate governance, Stakeholder management, Corporate social responsibility, Business ethics, Corporate citizenship, Sustainable Development Goals (SDGs)

Paper type Conceptual paper

\section{Introduction}

This theoretical and conceptual research paper argues that the basis for well-organized capital markets with companies with integrity and accountability is business ethics, corporate social responsibility (CSR) and good corporate citizenship. Since the financial crisis in 2008 and with the UN sustainable development goals since 2015(United Nations 2018a; United Nations 2018b) there has been increased focus on long-term investments and sustainability at capital markets (United Nations, 2020). In this perspective business ethics of investments, ownership and shareholding of

(C) Jacob Dahl Rendtorff. Published in Journal of Capital Markets Studies. Published by Emerald Publishing Limited. This article is published under the Creative Commons Attribution (CCBY 4.0) license. Anyone may reproduce, distribute, translate and create derivative works of this article (for both commercial and noncommercial purposes), subject to full attribution to the original publication and authors. The full terms of this license may be seen at http://creativecommons.org/licences/by/4.0/legalcode

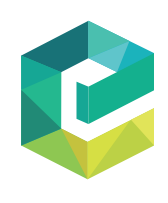

Journal of Capital Markets Studies Vol. 4 No. 1,2020 Emerald Publishing Limited 2514-4774 DOI 10.1108/JCMS-06-2020-0021 
JCMS

4,1

capitalmarketbusiness can beconceived as a combination of good corporate governance, CSRand stakeholder justice as the foundation of sustainability management (Elkington, 1997).

Thus, this conceptual paper applies the core of my argument for cosmopolitan business ethics based on corporate citizenship, CSR and stakeholder management on sustainable capital markets in relation to good corporate governance (Lorsch, 2000). The paper is a contribution to a specific discussion in relation to sustainability, stakeholder management, capital markets and corporate governance in the sense that it focuses on stakeholder management of corporate governance (Freeman and William, 1990; Philips and Freeman, 2010; Philips, 2011). Here, the challenge is to show how stakeholder management is essential for sustainable corporate governance for evaluating firms in financial institutions and capital markets.

This approach makes it possible to integrate corporate citizenship and business ethics with good governance of the firm as the basis for improving the investment and capital value of firms for owners and investors (Huse, 2009). Moreover, this is conceived as justification of sustainability investments in the framework of providing a foundation of management of the great transition toward a more sustainable society.

Conceiving corporate governance in the perspective of sustainability and the good citizen corporation means to integrate the idea of corporate governance in the larger framework of theories of corporate citizenship and good governance, which is based on earlier research on cosmopolitan business ethics (Rendtorff, 2009a, b, 2010b, 2011a, b, c, 2012, 2014c, 2017a, b, c). This approach in this paper is proposed as the basis for understanding business ethics of successful companies for sustainable investments at well-functioning financial systems and capital markets.

I would argue that this general and more profound conception of corporate governance related to capital markets is an ethical alternative to dominating technical and formal concepts of corporate governance - and even processual concepts that works on procedural and legal rules and guidelines for good and professional governance of the corporate board in order to protect the interests of shareholders and investors, which has become an important application of the concept of corporate governance at stock exchanges and capital markets (Huse, 2009; Monks Robert and Minow, 2004).

As closely linked to CSR and business ethics, corporate governance related to capital markets cannot be reduced to the legal and formal aspects of management of corporations, but may include a perspective of governance as conceived in the light of political philosophy and political theory, as it can be proposed as the framework for business ethics. This should also be conceived as the basis for understanding successful and sustainable companies at well-functioning capital markets, since long term investors like institutional investors, pension funds or other long-term investors need to focus on business ethics and CSR in order to ensure legitimacy of their investments.

In fact, concepts of sustainability management and triple bottom line with focus on the UN SDGs are essential elements of this approach to responsible corporate governance of companies seen from the perspective of ethical investments and sustainable capital markets. In this sense, the technical and legal aspects of corporate governance in order to promote dynamic investments in long-term perspectives have to be conceived within the framework of good corporate citizenship in relation to CSR and stakeholder management as the foundation of good corporate governance related to the global transition toward sustainable development.

With focus on sustainable corporate governance and capital markets, the flow of paper is structured in the following main sections: (2) Corporate citizenship, capital markets and corporate governance; (3) Corporate governance, finance and stakeholder management; (4) Corporate citizenship, sustainability, fairness and justice at capital markets; (5) Corporate citizenship and stakeholder responsibility; (6) Corporate Governance: Between shareholders and stakeholders; (7) Corporate citizenship, capital markets and the ethics of sustainable development goals (SDGs) and (8) Conclusion: Corporate citizenship and stakeholder management as conditions for SDGs at capital markets. 


\section{Corporate citizenship, capital markets and corporate governance}

With this theory of corporate citizenship, I would like to situate the theoretical concept of corporate governance of companies at capital markets within the framework of responsible stakeholder management (Rendtorff, 2009a). In the firm at capital markets, the shareholders, management and the board may be conceived as those who governs while the stakeholders are those who are governed. It is important to extend discussions of corporate governance beyond the legal and technical framework toward a general perspective of good governance like the one we find in political philosophy and social theory (Roseau and Net Czempiel, 1992; Huse, 2009).

We find the origins of this concept of governance in the classical theories of the republic. Governance was related to the public thing, "res publica". With the new focus on governance within political theory and political philosophy we meet an emphasis on the function of democracy (Rendtorff, 2009a). With the global developments of capital markets where there is increased focus on sustainability and UN SDGs there is increased need to justify the actions and activities of businesses and corporations from the perspective of democracy and political CSR (United Nations, 2018a, b).

This focus on governance of private business related to democratic legitimacy of business in global society means that the corporation needs to justify its activities to society in order to be legitimate at the stock exchange. To govern means to search for legitimacy and this is the relation between stakeholder management and new theories of political governance because both approaches focus governance understood as legitimate governance.

To situate corporate governance within this framework of political justification of investments and capital markets means to make the legal principles of governance dependent on the larger framework of good governance. From the point of view of political CSR and republican business ethics corporate governance is not only a functionalist term but relates more generally to concepts of the common good in society, which contributes to the determination of the value of the firm at stock markets.

This trend of emphasis of political CSR and democratic legitimacy of valuable companies for institutional investors is indeed present at stock markets in Scandinavia and Nordic companies. We can as an example mention one of the most valuable companies at the Danish Stock Exchange, the global Pharmaceutical and biotechnology Novo Group (with Novo Nordic and Novozymes) as valuable stocks at capital markets that have made response to global political legitimacy claims essential to corporate reporting and stock market reputation. Another example from Denmark is the global Wind systems producer Vestas that prioritizes the politics of Green transition as essential to corporate production and reputation.

Thus, the concept of corporate governance of successful companies at the stock exchange and long-term capital markets needs to include elements of stakeholder management and concerns for ethics codes and programs within the firm (Rendtorff, 2009a). Thus, ambitious companies need to integrate shareholder and stakeholder management if they want to be successful for investors at capital markets. The corporation has become a political agent who needs to search for legitimacy beyond the traditional economic sphere of internal justification. Here we need ethical management, since we should not forget that "the principles of who and what really counts depend on the interests and perceptions of managers" (Mitchell et al., 1997).

\section{Corporate governance, finance and stakeholder management}

Thus, well-functioning capital markets imply a move from shareholder management to stakeholder management as the core of good corporate governance. In this context, the concept
Sustainable Development Goals 
JCMS

4,1

of stakeholder salience is an essential indicator of valuable companies in terms of ethics and sustainability (Rendtorff, 2009a). Here, Mitchell, Agle and Wood have in their famous analysis of stakeholder salience showed how the ideas of power, legitimacy and urgency contribute with a stakeholder typology identifying nine important stakeholders categories that can be conceived as essential for ethical decision-making in firms: (1) Dormant stakeholders; (2) Discretionary stakeholders; (3) Demanding stakeholders; (4) Dominant stakeholders; (5) Dangerous stakeholders; (6) Dependent stakeholders; (7) Definitive stakeholders. But we may also mention (8) Latent stakeholders and (9) Nonstakeholders who are not perceived to be important for management of the firm (Rendtorff, 2009a).

If a company searches long-term legitimacy for institutional investors like governments or pension funds it must include this kind of stakeholder management in good corporate governance. Latent stakeholders could be dormant stakeholders like majority shareholders or external intruders who want to realize hostile take overs (Rendtorff, 2009a). This could be stakeholders who impose concern for sustainability and SDGs with urgency and legitimacy related to the core products and activities of the firm. Moreover, there may be representatives from civil society who function as discretionary stakeholders and require legitimacy action with no direct instrumental power or influence on the firm.

Such stakeholders like NGOs or Green movements may be candidates for corporate philanthropy in order to make the image of the firm more legitimate. But companies who want to have a reliable reputation on stock markets are also facing demanding stakeholders who are groups who have neither power nor legitimacy, but have some claim on the firm and make a lot of noise "like mosquitoes in the air" (Mitchell et al., 1997).

Thus, in order to achieve democratic legitimacy at the stock exchange and capital markets the company also needs to consider expectant stakeholders who like dormant stakeholders who are both powerful and legitimate in the corporation and who form a dominant coalition in the enterprise (Rendtorff, 2009a). They may have some mechanisms in place in board, public affairs office, etc. in order to maintain their position. In a democratic vision of corporate governance management needs to be respectful and diplomatic with regard to these stakeholders. This may be representatives of unions or activist shareholders to put demand of the company to be accepted for investments and exchange at capital markets. Dependent stakeholders are on the contrary stakeholders who lack power but have an urgent and legitimate claim on the firm, for example in connection with firm's responsibility for damaging action upon these stakeholders. With the contemporary challenges of climate change, global poverty, pandemics like coronavirus disease 2019 (COVID-19), dependent stakeholders are becoming much more significant and internal corporations need to have respectful and sustainable strategies toward such stakeholders.

A further indication of the important of stakeholder management for companies at capital markets and stock exchange of shares is the need to consider the natural environment as a stakeholder. The contemporary ecological crisis demonstrates that our natural environment as a dependent stakeholder is and extremely important and salient stakeholder. Dangerous stakeholders represent other groups of stakeholders who have claims of power and urgency. They may for example in the context of environmental critique of corporations use coercive means to advance stakeholder claims and therefore be dangerous.

Definitive stakeholders combine the categories of power, legitimacy and urgency. Those stakeholders are of course very important, and they can be dormant or dangerous stakeholders who are getting a stronger position (Mitchell et al., 1997). In the context of the contemporary transition to sustainable societies and sustainable development such stakeholders are often related to contemporary political movements and critique of corporations. Therefore, they may have strong impact on company's reputation on capital markets. Take for example the present willingness to invest in sin stocks like tobacco, pornography or alcohol production. 
From the point of view of business ethics and corporate citizenship, it is the task of corporate governance as stakeholder management to formulate policies and strategies that give the company trust and legitimacy at capital markets by moving beyond immanent concern for shareholders toward a broader concern for all implied stakeholders (Crane and Matten, 2016). Nevertheless, stakeholder management is not easy and there may be many obstacles for improving corporate reputation and legitimacy at capital markets. The political pressure on corporations in increasing with more challenges and problems of business and society (Rendtorff, 2009a). This is indeed the case with the challenge of implementing the SDGs as leadership models in business and management.

Stakeholder management is very complex and there may be culture clash between different groups and stakeholders and management and there may be strong problems in uniting the different views of the action of the firm (Rendtorff, 2009a). This is related to the problems of conflict between different stakeholders which may be so strong that it is difficult to find a possible solution that will satisfy all the different individuals and groups (Mitchell et al., 1997). Even though the corporation takes into stakeholder salience to improve reputation and legitimacy at stock markets, it may be difficult to create a political profile that satisfies all political positions with regard to the role and function of the corporation at the stock exchange and at capital markets.

\section{Corporate citizenship, sustainability, fairness and justice at capital markets}

On this foundation, with close relations between stakeholder management and corporate governance the link between the SDGs, CSR and the concept of the good citizen corporation can be developed by using the principle of fairness as basis for just relations to stakeholders. This concept of justice is very important for well-functioning capital markets, based on trust, integrity and accountability. Belief and trust in financial markets are essential for attracting investors and ensure sustainable profits at the long term.

Therefore, justice at capital markets implies institutional security for investors and owners and this implies faith and trust in democratic institutions based on a well-ordered society. At another level this relates to specific issues of justice at capital markets for example gender justice in the board room and general respect for diversity at financial markets. Indeed, ethical principles of respect for autonomy, dignity, integrity and vulnerability are important for justice in corporate governance as the basis for legitimacy at financial markets.

The need for justice at financial markets and capital markets has increased because of general social skepticism toward finance professionals and investors. The criticism is that even though there is more focus sustainability in society financial investors are still strictly focusing on profits and profit-maximization. Nevertheless, the global agenda of transformation toward sustainable development of the United Nation's SDGs demonstrate increased need for ethical principles at financial markets.

The political theory of John Rawls can here be applied as the foundation for understanding ethics, fairness and trust of financial markets. This theory of justice is primarily developed in Rawls' famous book A Theory of Justice (Rawls, 1964). Rawls defends a conception of justice as fairness based on two principles as the basic structure of society and social interaction: (1) Political freedom of all citizens; (2) The principle of difference stating that social inequality can only be justified in so far it is for the benefit of the least advantaged in society (Rawls, 1971). This second principle is John Rawls' justification of the freedom and equality of free markets economies with financial markets and capital markets as the core of capitalism since they contribute to increase of the wealth and income of the least advantaged.

I share this view of John Rawls although it may be a very difficult task to decide in concrete circumstances what inequality is to be justified as substantial benefit for the poorest in society. However, it is important to emphasize the relation between community, fairness and 
JCMS 4,1

ethics. In order to have an institutional foundation of financial markets it is necessary with a vision of the common good and of the self as participant in society in order to justify his principles of justice.

This was the reason why Rawls in PoliticalLiberalism (1992) has restated his view in terms of a "overlapping consensus" between "comprehensive doctrines" as a political view on justice, which does not exclusive rest on a rational metaphysics. In arguing for justice as fairness as the basis for the ethics of financial institutions and capital markets I rely this late reinterpretation of the concept of justice, which Rawls has developed explicitly in his argument for justice as fairness (Rawls, 2001). Rawls defines justice as fairness as a political conception for a democratic society (Rawls, 2001, p. 21) which develops a system of fair cooperation founded in a reasonable overlapping consensus (Rawls, 2001, p. 33). The two principles of justice are defined as principles for background institutions of a well-ordered society and this can also be considered as the normative basis for financial institutions and capital markets. As an ideal of institutional justice, fairness helps to ensure trust, integrity and accountability among finance professionals and these principles also provide basis for just decisions related to different stakeholders (Philips, 2003).

In the light of this focus on stakeholder fairness and good corporate citizenship at financial markets, we can propose stakeholder theory in finance and corporate governance as a manner of maximizing search for the common good of stakeholders, which is expressed in the idea of sustainable development. To argue for stakeholder fairness in the light of corporate citizenship and business ethics means a fair account of the involved stakeholders in decisionmaking. John Rawls' theory of political liberalism can in this context be applied as the foundation of a global cosmopolitan business ethics oriented toward sustainable development. In global financial institutions the SDGs can provide a global strategic frame for stakeholder fairness.

Thus, fairness is an essential ethical principle for understanding trade and exchange in financial institutions and capital markets. Fairness as an interpretation of stakeholder justice taking everybody into account means that market interactions are founded on fundamental ethical principles of transparency, disclosure of information, respect for diversity and equal opportunity for example with very strict procedures against insider trading. The most important way to ensure fairness in financial institutions and capital markets is an extensive application of stakeholder management.

Here emerges a difficult question of justification of lack of political democracy of corporations. Such inequality may be justified at the basis of the principle of difference indicating the need for economic efficiency for growth of wealth in society. However, this is also an argument against the so-called "stakeholder-paradox" stating that an organization cannot have fiduciary duties to other constituencies than shareholders because this would eliminate the meaning of the concept of "fiduciary duty" (Goodpaster, 1991; Philips, 2003, p. 69). Viewing the corporation in the perspective of the original position means it is possible to argue for a multitude of fiduciary duties in order to accomplish the duty of responsibility and of justice as fairness.

On this basis corporate governance as stakeholder management can be conceived as a response to societal expectations of corporate citizenship and contribution to the common good of society. But stakeholder management is also legitimate in the perspective of strategic management, because stakeholders have legitimate claims of being treated justly by the organizations. Different groups of stakeholders are legitimate stakeholders to the extent they have justified claims of being treated with fairness of the organization. In the perspective of corporate citizenship, the principles of responsibility and sustainability must be included in this account of fair treatment of stakeholders.

Therefore, stakeholders who do not directly cooperate with the corporations and therefore do not have a direct normative claim and a correspondent obligation to be accounted for as its 
core constituencies may have a derivative claim of being taken into account. Accordingly, following this claim we can say that civil society organizations or social activists in relation to the activities of financial institutions or capital markets can have legitimate claims in so far as they are representatives of core constituencies of the corporations for example employees or local communities.

\section{Corporate citizenship, sustainability and stakeholder responsibility}

We can develop this approach with reference to Edward Freeman's important principles of stakeholder responsibility as foundation for stakeholder engagement for sustainable development. The principles of stakeholder responsibility can be considered as essential for corporate governance and for financial markets and exchange of shares of businesses at capital markets. Stakeholder management is a strategy of increased self-perception as the basis for decision-making (Freeman, 1994). This is the essence of Edward Freeman's Principles of Stakeholder Management. In relation to the debate on CSR and corporate governance Freeman argues for "corporate stakeholder responsibility" as a much more pragmatic and honest way to defend a social approach to corporate responsibility. These principles can be considered as a way to work for fairness in stakeholder relations of businesses in financial institutions and capital markets.

This implies the following principles of corporate stakeholder responsibility that Freeman has defended on numerous occasions (Freeman and Velamuri, 2006):

(1) Stakeholder interests go together over time;

(2) Stakeholder consists of real people with names and faces and children. People are complex;

(3) We need solutions to issues that satisfy multiple stakeholders simultaneously;

(4) We need intensive communication and dialog with stakeholders - not just those who are friendly;

(5) We need to have a philosophy of voluntarism, to manage stakeholder relationships ourselves rather than third parties such as governments;

(6) We need to generalize the marketing approach;

(7) Everything that we do serves stakeholders. We never trade off the interests of one vs the other continuously over time;

(8) We negotiate with primary and secondary stakeholders;

(9) We constantly monitor and redesign processes to make them better serve our stakeholders;

(10) We act with purpose that fulfills our commitment to stakeholders. We act with aspiration toward fulfilling our dreams.

These perspectives for stakeholder responsibility can be considered as important for stakeholder engagement in financial institutions, investments and financial markets (Freeman and Velamuri, 2006). Following Freeman's stakeholder principles means that not only managers of firms but also investors and capital market firms use stakeholder management to evaluate performance of firms in the perspective of not only the triple bottomline but indeed also in relation the 17 bottom-lines of the UN SDGs (United Nations, 2020). Using stakeholder management for evaluation of performance of companies at capital markets means that investors use stakeholder analysis as an integrated dimension of
Sustainable Development Goals 
JCMS

4,1

investment strategies and also develop stakeholder engagement strategies in order to ensure close relations with the strategies and policies of the firm.

In fact, we can say that Freeman's principles of stakeholder management can be used to formulate a fundamental revision of stakeholder theory in comparison with traditional concepts that would place the corporation in the center of the stakeholder diagram with the different stakeholders of the corporation placed around the corporation. A more progressive way to express the idea of corporate citizenship within stakeholder management would be not to situate the corporation in the center of the diagram, but rather conceive it as one among other stakeholders contributing to the common good of society. The model of stakeholder management has been practiced with success by the Danish corporation Novo Nordic that presented itself as a part of a stakeholder web, where the firm sees itself as an important servant of society. With a parallel to financial institutions and capital markets, such institutions should present themselves at good corporate citizens searching legitimacy in service for society. In this perspective, the firm is no long in the center of stakeholders but rather one among other stakeholders who work together to improve the good of all individuals in community. This revised version of stakeholder theory can be formulated as a model of the firm where the firm is only one stakeholder among many serving the common good of society.

\section{Corporate governance: between shareholders and stakeholders}

Thus, there is a close relation between stakeholder management, good corporate citizenship, CSR and corporate governance. This is a reflection that is based on the development of earlier research on ethical management (Pedersen and Rendtorff, 2004; Mattsson and Rendtorff, 2006; Rendtorff and Mattsson, 2012; Rendtorff, 2015b, 2017a, b, 2019a, b, c). Corporate governance based on CSR implies that that the board and central management acknowledge to be responsible for good corporate governance based on concern for fairness as stakeholder justice and respect for based ethical principles of autonomy, dignity, integrity and vulnerability. Good corporate governance implies a program for values-driven management, ethics or compliance that relates to the stakeholders of the corporation.

In this context, the ethical principle of respect for integrity is essential for good financial institutions and ethical capital markets. Integrity expresses the unity and wholeness of the organization with regard to trust, honesty and moral identity. There is a close connection between individual and organizational integrity. Indeed, history, culture and values of the organization contributes to the formation of individual and organizational integrity that defines the moral compass of individuals and institutions in finance and capital markets. Here, there is a close relation between integrity and responsibility. Thus, CSR and values define integrity and the sum of corporate structures of codes and conducts, strategies and policies are the basis for institutional responsibility. This means that the principle of integrity implies that corporate integrity is defined as a virtue of uncorrupted character, a value coherence of organizations which forms accountability, trust and transparency and functions as the basis for judgment and actions with integrity in investment firms acting on capital markets. Accordingly, to focus on integrity in financial institutions may be conceived as a kind of sleep test ethics, where values and ethics are considered as the basis for good and fair individual decision-making taking into account relevant stakeholders in order to ensure fairness and justice in financial institutions and capital markets

However, there are also important economic arguments for improving corporate governance with focus on business ethics at capital markets. In the light of economic theory of the firm corporate governance is first of all about creating efficient structures of governance of the firm. The system of modern capitalism is argued to be the most efficient and the economic institutions of market economies are providing necessary reduction of transaction cost for economic actions. We have firms with governance structures and 
shareholders simply because it is the most efficient way to provide basis for economic progress in society. This is the view of John Boatright who wants to justify the exclusive and decisive role of the shareholder from this economic perspective (Boatright, 2002).

Even though we have defended the importance of stakeholder theory and a broader view of economic rationality we may agree that within the present economic system it is important to protect the role of the shareholder with regard for corporate governance. Transparency, accountability and stability of corporate governance is a condition for healthy financial institutions and capital markets because shareholders can have clear knowledge about risk behavior. But this also means that the shareholders take their roles as stakeholders seriously and are conscious about their rights and possibilities of control (Crane and Matten, 2016). The many debates in the US and in many European countries since the financial crises are due to the separation between shareholders as owners and the executive managers and boards of many corporations. The potential conflict between shareholders and managers concerning returns and aims of the corporations has after collapses of big companies following the financial crisis and later global crisis become an even hotter topic in business debates.

\section{Corporate citizenship, capital markets and the ethics of sustainable development goals (SDGs)}

The ethics of corporate governance is about defining and following the duties of the corporate board and directors toward the shareholders. This ethics is in particular important in order to create well-functioning capital markets with focus on sustainable development and green transition to an eco-friendlier society. Managers have fiduciary duties to shareholders and to work for their interest. However, given the contemporary developments toward a more sustainable society, which implies the need for global corporate citizenship and the importance of stakeholder engagement in capital markets it is important to argue that the ethics of corporate governance is not restricted to shareholders but should be included in the broader perspective of stakeholder management (Rendtorff, 2009b, 2015c, 2017d). The corporate boards also have duties toward a wider specter of stakeholders in order to integrate investments and capital markets with the UN SDGs as the ultimate horizon for business ethics and corporate citizenship.

This means that stakeholder engagement in financial institutions and capital markets implies integration of the SDGs in strategies for investments and evaluation of performance of firms. The SDGs follow up on the global politics of sustainability since the Brundtland World Commission on the Environment's report Our Common Future in 1987. By sustainable development is understood the fundamental responsibility to preserve the Earth for future generations. Such a vision of sustainability should be integrated into the strategies of investors and be fundamental to the codes of conducts for ethical investment that integrates economic, social and economic concerns in a general framework for corporate governance at capital markets.

Thus, the UN SDGs, which were decided at the United Nations General Assembly session in 2015 can be promoted as fundamental bottom-lines for ethical and sustainable investment strategies for long term capital markets that promotes the principles of fairness and integrity in the framework of good corporate citizenship with stakeholder engagement and stakeholder management. In this perspective the SDGs are proposed as new ethical guidelines for responsible investments at capital markets.

In the future the ethics of capital markets needs to consider the SDGs as essential for responsible investments. Many companies and businesspeople are already interested in the implicit philosophy of the UN SDGs. Present in the formulation of the SDGs by the United Nations we find first the ethics of global responsibility (Rendtorff, 2017a, 2019a, b, d). Moreover, there is a strong presence of ethical principles that gives us an opportunity to evaluate the values and ethical principles of the SDGs.
Sustainable Development Goals 
JCMS

4,1

In headlines the 17 SDGs of the UN 2030 Transforming the World Agenda are the following: (1) No poverty; (2) Zero hunger; (3) Good health and wealth being; (4) Quality education; (5) Gender equality; (6) Clean water and sanitation; (7) Affordable and clean energy; (8) Decent work and economic growth; (9) Industry innovation and infrastructure; (10) Reduced inequalities; (11) Sustainable cities and communities; (12) Responsible consumption and production; (13) Climate action; (14) Life below water; (15) Life on land; (16) Peace, justice and strong institutions and (17) Partnerships for the goals (UN, 2015).

Today, these SDGs emerge as an essential challenge for capital markets. What is needed is an operationalization of the SDGs with focus on specifying targets and indicators for each of the 17 goals (UN, 2015) that can be applied as measures for ethical investments for the benefit of society.

This vision of the SDGs need to be endorsed at financial markets. Businesses now play an important role in this sustainable development and many businesses in Europe and the world have embraced the agenda (Rendtorff, 2017a, 2019a, b, d). Moreover, the European Union regards CSR and ecological sustainability basic components in the formation of new partnerships both locally and internationally. It highlights in this context that not only multinational companies but also small and medium enterprises (SMEs) can help to build commitment to CSR of businesses. Accordingly, the capital market investments need to focus on the SDGs in order to develop ethical investment strategies for sustainable business. With this SDG investment strategies focus on the need for a great ecological and economic transformation of business in the world system.

\section{Conclusion: corporate citizenship and stakeholder management as conditions for SDGs at capital markets}

Thus, in conclusion we can emphasize the close relation between corporate citizenship, stakeholder management and CSR for good corporate governance for development of strategies developing capital markets for ethical investments in the SDGs. From this perspective it is wrong to limit corporate governance to concern a close relation between owners and management, because there increased focus on the social legitimacy of the corporation indicate a close relation between corporate governance, corporate citizenship and CSR in the future of sustainable capital markets based on the SDGs. In this sense, the reflections in this paper on corporate governance and stakeholder management can also be seen as the basis of a concept of philosophy of management. (Rendtorff, 2010a, 2013a, b, c, d, 2014b, 2015a, 2017c, 2019d). This is also because the concept of sustainable investments needs to be analyzed in the fundamental perspective of the theoretical foundation of the SDGs.

The development of new external and internal forms of governance is important to improve the focus on the SDGs of financial institutions and capital markets. Strong ownership with focus on sustainability is important, and this may be improved with the rules of corporate governance. In this context we can emphasize that the values of transparency, openness, integrity and fairness are important for corporate governance that aims at integrating the SDGs in corporate performance at financial markets. Moreover, the communication of such standards of sustainable corporate governance is important in order to create relations of trust in the corporation.

This includes stakeholder engagement by use of a program for sustainable development or a program of compliance with SDGs that includes engagement for different stakeholders of the firm. Such programs must be formulated in accordance with international guidelines and rules about CSR and triple bottom-line management, based on the vision for People, Planet and Profits (Elkington, 1997), which is essential for the current transition to sustainable development built on the UN SDGs. On this basis the firm formulates concrete strategy and 
policy plans for further development of the firm. Sustainable corporate governance and capital markets implies fair concern and respect for the ethical principles of stakeholder management, integrity and organizational fairness.

Sustainable Development Goals

\section{References}

Boatright, J. (2002), "Justifying the role of the shareholder", in Bowie, N.E. (Ed.), The Blackwell Guide to Business Ethics, Basil Blackwell, Oxford.

Crane, A. and Matten, D. (2016), Business Ethics. A European Perspective, Oxford University Press, Oxford.

Elkington, J. (1997), Cannibals with Forks, The Triple Bottom Line of 21st Century BusinessCapstone, London.

Freeman, R.E. (1994), "The politics of stakeholder theory: some future directions", Business Ethics Quarterly, Vol. 4 No. 4, pp. 409-422.

Freeman, R.E. and Velamuri, S.R. (2006), "A new approach to CSR: company stakeholder responsibility", in Kakabadse, A. and Morsing, M. (Eds), Corporate Social Responsibility, Palgrave Macmillan, London.

Freeman, R.E. and William, M.E. (1990), “Corporate governance: a stakeholder interpretation”, Journal of Behavioral Economics, Vol. 19 No. 4, pp. 337-359.

Goodpaster, K.E. (1991), "Business ethics and stakeholder analysis”, Business Ethics Quarterly, Vol. 1 No. 1, pp. 53-73.

Huse, M. (2009), Boards, Governance and Value Creation. The Human Side of Corporate Governance, Cambridge University Press, Cambridge.

Lorsch, J.W. (2000), Empowering the Board" in Harvard Business Review on Corporate Governance, Harvard Business School Press, Cambridge, MA, pp. 22-23.

Mattsson, J. and Rendtorff, J.D. (2006), "E-marketing ethics: a theory of value priorities", International Journal of Internet Marketing and Advertising, Vol. 3 No. 1, pp. 35-47.

Mitchell, R.K., Agle, B.R. and Wood, D.S. (1997), "Toward a theory of stakeholder identification and salience: defining the principle of who and what really counts", Academy of Management Review, Vol. 22 No. 4, pp. 853-886.

Monks Robert, A.G. and Minow, N. (2004), Corporate Governance, 3rd ed., Blackwell Publishing, Oxford.

Pedersen, J.S. and Rendtorff, J.D. (2004), "Value-based management in local public organizations: a Danish experience", Cross Cultural Management, Vol. 11 No. 2, pp. 71-94.

Philips, R. (2003), Stakeholder Theory and Organizational Ethics, Berrett-Koehler, Inc, San Francisco.

Philips, R. (2011), Stakeholder Theory. Impacts and Prospects, Edward Elgar, Cheltenham.

Philips, R. and Freeman, R.E. (Eds) (2010), Stakeholders, An Elgar Reference Collection, Edward Elgar, Cheltenham.

Rawls, J. (1992), Political Liberalism, Harvard University Press, Cambridge, MA.

Rawls, J. (1964), "Legal obligation and the duty of fair play", in Hook, S. (Ed.), Law and Philosophy, New York University Press, New York, NY.

Rawls, J. (1971), A Theory of Justice, Harvard University Press, Cambridge, MA.

Rawls, J. (2001), Justice as Fairness. A Restatement, Harvard University Press, Cambridge, MA.

Rendtorff, J.D. (2009a), Responsibility, Ethics and Legitimacy of Corporations, Copenhagen Business School Press, Copenhagen.

Rendtorff, J.D. (2009b), "Basic ethical principles applied to service industries", Service Industries Journal, Vol. 29 No. 1, pp. 9-19, doi: 10.1080/02642060802116404. 
JCMS

4,1

\section{8}

Rendtorff, J.D. (2010a), "Philosophy of management: concepts of management from the perspectives of systems theory, phenomenological hermeneutics, corporate religion and existentialism", in Koslowski, I.P. (Ed.), Elements of a Philosophy of Management and Organization, Springer, Studies in Economic Ethics and Philosophy, Heidelberg, pp. 19-47.

Rendtorff, J.D. (2010b), Power and Principle in the Market Place: On Ethics and Economics, Ashgate, London.

Rendtorff, J.D. (2011a), "Business ethics, strategy and organizational integrity: the importance of integrity as a basic principle of business ethics that contributes to better economic performance", in Wankel, I.C. and Stachowicz-Stanusch, A. (Eds), Handbook of Research on Teaching Ethics in Business and Management Education, IGI global, New York, NY, pp. 274-288, doi: 10.4018/978-1-61350-510-6.ch016.

Rendtorff, J.D. (2011b), "Institutionalization of corporate ethics and social responsibility programs in firms", in Buhmann, I.K., Roseberry, L. and Morsing, M. (Eds), Corporate social and Human Rights Responsibilities: Global, legal and Management Perspectives, Palgrave Macmillan, London, pp. 244-266.

Rendtorff, J.D. (2011c), “Corporate citizenship as organizational integrity”, in Pies, I.I. and Koslowski, P. (Eds), Corporate Citizenship and New Governance: The Political Role of Corporations, Springer, Studies in Economic Ethics and Philosophy, Dordrecht, Heidelberg, London, NY, pp. 9-91.

Rendtorff, J.D. (2012), "Business ethics", in Chadwick, I.R. (Ed.), Encyclopedia of Applied Ethics, Academic Press, San Diego, pp. 365-372, (2 udg., Bind 1).

Rendtorff, J.D. (2013a), "Basic concepts of philosophy of management and corporations", in Luetge, I.C. (Ed.), Handbook of the Philosophical Foundations of Business Ethics, Springer Science+Business Media, Dordrecht, Heidelberg, London, NY, pp. 1361-1386.

Rendtorff, J.D. (2013b), "Philosophical theories of management and corporations", in Luetge, I.C. (Ed.), Handbook of the Philosophical Foundations of Business Ethics, Springer Science + Business Media, Dordrecht, Heidelberg, NY, London, pp. 1409-1432.

Rendtorff, J.D. (2013c), "Recent debates in philosophy of management”, in Luetge, I.C. (Ed.), Handbook of the Philosophical Foundations of Business Ethics, Springer Science + Business Media, Dordrecht, Heidelberg, NY, London, pp. 1433-1457.

Rendtorff, J.D. (2013d), "The history of the philosophy of management and corporations", in Luetge, I.C. (Ed.), Handbook of the Philosophical Foundations of Business Ethics (s. 1387-1408), Springer Science+Business Media, Dordrecht, Heidelberg, London, NY, pp. 1387-1408.

Rendtorff, J.D. (2014b), French Philosophy and Social Theory: A Perspective for Ethics and Philosophy of Management, No. 49, Springer International Publishers, Cham.

Rendtorff, J.D. (2014c), "Risk management, banality of evil and moral blindness in organizations and corporations", in Luetge, I.C. and Jauernig, J. (Eds), Business Ethics and Risk Management, No. 43, Springer Science+Business Media. Ethical Economy, Dordrecht, pp. 45-71.

Rendtorff, J.D. (2015a), "Case studies, ethics, philosophy and liberal learning for the management profession”, Journal of Management Education, Vol. 39 No. 1, pp. 36-55.

Rendtorff, J.D. (2015b), "The need for a theoretical reexamination of sustainability in economics and business", in Aras, I.G. (Ed.), Sustainable Markets for Sustainable Business: A Global Perspective for Business and Financial Markets, Gower Publishing. Finance, Governance and Sustainability: Challenges to Theory and Practice, Farnham, pp. 41-58.

Rendtorff, J.D. (2015c), "Integrity”, concept of. Ten Have, I.H. (Ed.), Encyclopedia of Global Bioethics, Springer Science + Business Media, pp. 1-7, doi: 10.1007/978-3-319-05544-2.

Rendtorff, J.D. (2017a), Cosmopolitan Business Ethics: Towards a Global Ethos of Management, Routledge. Finance, Governance and Sustainability: Challenges to Theory and Practice Series, London.

Rendtorff, J.D. (2017b), "Creating shared value as institutionalization of ethical responsibilities of the business corporation as a good corporate citizen in society", in Wieland, I.J. (Ed.), Creating 
Shared Value: Concepts, Experience, Criticism, No. 52, Springer International Publishers, Cham, pp. 119-139, p. 1.

Rendtorff, J.D. (2017c), Perspectives on Philosophy of Management and Business Ethics: Including a Special Section on Business and Human Rights, No. 51, Springer Ethical Economy, Cham.

Rendtorff, J.D. (2017d), "The Danish model of corporate citizenship: the Novo group”, in O'Higgins, I.E. and Zsolnai, L. (Eds), Progressive Business Models: Creating Sustainable and Pro-social Enterprise, Palgrave Macmillan, Palgrave Studies in Sustainable Business In Association with Future Earth, London, NY, pp. 221-240, doi: 10.1007/978-3-319-58804-9_10.

Rendtorff, J.D. (2019a), "Sustainable development goals and progressive business models for economic transformation”, Local Economy, Vol. 34 No. 6, pp. 510-524, doi: 10.1177/0269094219882270.

Rendtorff, J.D. (2019b), "The concept of business legitimacy: corporate social responsibility, corporate citizenship, corporate governance as essential elements of ethical business legitimacy", in Crowther, I.D., Seifi, S. and Wond, T. (Eds), Responsibility and Governance: The Twin Pillars of Sustainability, Springer VS Approaches to Global Sustainability, Markets, and Governance, Switzerland, pp. 45-60.

Rendtorff, J.D. (2019c), "The honest businessperson: cosmopolitan theory and cultural praxis (the example of Denmark and Scandinavia)", in Lütge, I.C. and Strosetzki, C. (Eds), The Honorable Merchant - Between Modesty and Risk-Taking: Intercultural and Literary Aspects, No. 56, Springer. Ethical Economy, Cham, pp. 41-53.

Rendtorff, J.D. (2019d), Philosophy of Management and Sustainability: Rethinking Business Ethics and Social Responsibility in Sustainable Development, Emerald Group Publishing, Bingley.

Rendtorff, J.D. and Mattsson, J. (2012), "Ethics in the bank internet encounter: an explorative study", Journal of Information, Communication and Ethics in Society, Vol. 10 No. 1, pp. 36-51, doi: 10. 1108/14779961211210649.

Roseau, J. and Net Czempiel, E.O. (1992), Governance without Government, Order and Change in World Politics, Cambridge University Press, Cambridge.

United Nations (2015), Sustainable Development Goals, available at: https://sustainabledevelopment.un. org/post2015/transformingourworld/publication (accessed 30 June 2020).

United Nations (2018a), Transforming Our World: The 2030 Agenda for Sustainable Development, United Nations, New York.

United Nations (2018b), United Nations Global Compact, United Nations, New York, available at: https://www.unglobalcompact.org/ (accessed 30 June 2020).

United Nations (2020), Sustainable Development Goals Report, United Nations, New York.

\section{Corresponding author}

Jacob Dahl Rendtorff can be contacted at: jacrendt@ruc.dk
Sustainable Development Goals 